\title{
Do the Queensland Regulations Governing the Refund of Motor Vehicle Registration Fees Breach s 92 of the Commonwealth Constitution?
}

\author{
Bede Harris ${ }^{1}$ \\ ${ }^{1}$ School of Accounting and Finance, Charles Sturt University, Australia \\ Correspondence: Dr Bede Harris, School of Accounting and Finance, Charles Sturt University, P O Box 789, \\ Albury NSW 2640, Australia. E-mail: beharris@csu.edu.au
}

Received: August 15, 2019

Accepted: August 29, 2019

Online Published: November 28, 2019

doi:10.5539/jpl.v12n4p8

URL: https://doi.org/10.5539/jpl.v12n4p8

\begin{abstract}
The federal system in Australia imposes inconvenience on people. One of these inconveniences arises from the fact that each State and Territory has its own vehicle registration regime. In contrast to other States in Australia, purchasers of vehicles from outside Queensland suffer from a particular burden in that they are denied a refund of the unexpired portion of vehicle registration fees. In this article it is argued that that denial is unlawful both as a matter of the interpretation of the applicable Regulations and because it infringes s 92 of the Commonwealth Constitution, which prohibits the imposition of protectionist burdens on interstate trade and commerce.
\end{abstract}

Keywords: Australia, Commonwealth, constitution, constitutional, discrimination, extraterritoriality, federalism, inter-State, interpretation, motor, presumption, protectionist, Queensland, registration, s 92, State, statute, statutory, Territory, trade, vehicle

\section{Introduction}

In addressing the question of whether the statutory provisions in Queensland infringe s 92 of the Commonwealth Constitution, this article focusses first on the interpretation of those provisions and then on the constitutional issues. Part 2 of this article examines legislation governing the entitlement to a refund of fees for unexpired motor vehicle registration in various States and Territories of Australia. Part 3 examines the law governing vehicle fee refunds in Queensland and its interpretation. Part 4 analyses s 92 of the Commonwealth Constitution and case law interpreting it. Part 5 argues that the Queensland regime is constitutionally invalid under s 92 in so far as it denies a refund to out of State purchasers of Queensland-registered vehicles. Part 6 concludes with a discussion of what steps could be taken to recover refunds unlawfully withheld.

\section{Motor Vehicle Registration Refunds in Various Australian Jurisdictions}

In Australia, motor vehicle registration falls within the legislative competence of the States and Territories. The result is that there is a patchwork of statutory regimes across the country. Compliance with them is particularly inconvenient in two circumstances: where a person purchases a motor vehicle from one jurisdiction while resident in another, or when a person changes their residence from one jurisdiction to another, taking their vehicle with them. In either instance, the person must register the vehicle in their jurisdiction of residence and de-register it in the jurisdiction from which the vehicle came. The focus of this article is the first circumstance that is, where a person in one State engages in interstate trade by buying a vehicle registered in another State.

In most Australian jurisdictions, registered owners who de-register a vehicle are entitled to a refund of the 'unexpired portion' of the annual registration fee. So, for example, if the annual registration fee for a vehicle was paid in January 2019 and the vehicle is de-registered at the end of August 2019, the registered owner would be entitled to a pro rata refund of four months worth of fees (sometimes minus an administrative fee for de-registration). This is what is provided for by legislation in New South Wales, ${ }^{1}$ Victoria, ${ }^{2}$ the ACT, ${ }^{3}$ the

\footnotetext{
${ }^{1}$ Section 125 of the Road Transport (Vehicle Registration) Regulation 2017 (NSW).

${ }^{2}$ Section 106 of the Road Safety (Vehicles) Regulations 2009 (Vic).

${ }^{3}$ Section 14 of the Road Transport (General) Regulation 2000 (ACT).
} 
Northern Territory, ${ }^{4}$ South Australia ${ }^{5}$ and Tasmania, ${ }^{6}$ which provides for a person to receive a refund of unexpired registration fees if cancelling the registration of a vehicle in any of those States, irrespective of where the applicant lives. This means that a person who purchases a car from one of these States, de-registers it in that State and then registers it in another, will be able to obtain a refund of registration from the government of the State in which the vehicle originated. Matters are however different under the law applicable in Queensland.

\section{The Queensland Legislation and Its Interpretation}

In Queensland, motor vehicle registration is governed by the Transport Operations (Road Use Management-Vehicle Registration) Regulation 2010 (Qld). Part 6 Division 2 of the Regulations list a number of circumstances in which a motor vehicle's registration may be cancelled. These are at the request of the registered operator of the vehicle in a number of circumstances, ${ }^{7}$ including if the vehicle has been taken out of the State. ${ }^{8}$ The registration can also be cancelled if it comes to the notice of the person administering the Regulations that the vehicle has been registered in another State ${ }^{9}$ at the request of local government (for example if the vehicle is to be disposed of in accordance with a local law) ${ }^{10}$ or if the vehicle has been forfeited to the State in accordance with criminal enforcement legislation. ${ }^{11}$ Regulation 56 states that if a vehicle's registration was cancelled under any of these provisions, a refund of the unexpired portion of the vehicle registration fee must be paid to 'the person who was the registered operator immediately before the cancellation.'

On its internet page informing the public what happens when a vehicle is moved out of the state, ${ }^{12}$ the Queensland Transport Department states that a person who moves from Queensland and takes their vehicle with them can get a refund of the unexpired licence fee if they register the vehicle in another State and then apply to the Department for the Queensland registration to be cancelled. However, the website also says:

A refund will only be issued to the registered operator of the Queensland registered vehicle - this is the person who the vehicle is registered to. If you're not the registered operator of a vehicle you cannot get a refund.

The effect of this is that a person from another State who purchases a vehicle from a registered operator in Queensland cannot get a refund even if they (the purchaser) has registered the vehicle in that other State because, as the website information shows, the Regulations are being applied in such a way as to permit a refund to be paid only to the person to whom the motor vehicle was registered in Queensland. Is this method of application of the Queensland legislation is correct?

What is meant by 'registered operator' in Regulations 54 and 56 is key to the question of who is eligible to receive a refund. The starting point in interpreting a statute is the literal approach, according to which words in a statute are given their ordinary dictionary meaning. ${ }^{13}$ 'Registered operator' is defined in Regulation 5 as 'the person in whose name the vehicle is currently registered.' There is nothing in this definition which restricts the definition of 'registered operator' to a person living in Queensland. Therefore, on a literal interpretation of Regulation 5, if a person from outside Queensland has purchased a Queensland registered vehicle from someone in Queensland and has then registered it in another State, one must conclude that, under the Regulations, that person has become the 'registered operator' of the vehicle in that State. Furthermore, if that person then applies to the Queensland Department of Transport to have the Queensland registration cancelled, they are applying in their capacity as the person 'who was the registered operator immediately before the cancellation,' and would therefore be eligible to receive a refund in accordance with Regulation 56. The fact that the vehicle would be registered both in Queensland and in the other State during the period between its registration in that other State and its cancellation in Queensland does not affect that conclusion. If the intent of the Regulations was to apply in such a way as to deny a refund to an out of State resident, then Regulation 5 should have defined 'registered operator' as 'a person in Queensland in whose name the vehicle is currently registered.' But it was not phrased

\footnotetext{
${ }^{4}$ Section 132 of the Motor Vehicles Act 1949 (NT).

${ }^{5}$ Section 81 of the Motor Vehicles Regulations 2010 (SA).

${ }^{6}$ Section 112 of the Vehicle and Traffic (Driver Licensing and Vehicle Registration) Regulations 2010 (Tas).

${ }^{7}$ Regulation 54.

${ }^{8}$ Regulation 54(1)(b)(ii)

${ }^{9}$ Regulation 55.

${ }^{10}$ Regulation 55A.

${ }^{11}$ Regulation 55B.

${ }^{12}$ https://www.qld.gov.au/transport/registration/transfer/interstate

${ }_{13}$ Amalgamated Society of Engineers v Adelaide Steamship Co Ltd (1920) 28 CLR 129, 161-2, Higgins J.
} 
that way and therefore, if one adopts the literal approach, the implementation of Regulation 5 as if it was phrased that way is ultra vires the Regulations.

One must however consider a counter-argument, based on the presumption against extraterritoriality, which is contained both in s 35(1)(b) of the Acts Interpretation Act 1954 (Qld) and in the common law. ${ }^{14}$ Section 35(1)(b) states that 'a reference to a locality, jurisdiction or other thing is a reference to such a locality, jurisdiction or other thing in and of Queensland.' Whether the word 'thing' includes a legal state such as a motor vehicle being registered is moot, as the word 'thing' is not defined in the Act. However, the common law presumption against extraterritoriality is broad enough to apply to a legal transaction or status such as registration. Under the common law, it is presumed that a statute applies only to matters occurring within the jurisdiction that enacted it, unless the statute applies extraterritorially by express words or necessary implication. ${ }^{15}$ If this presumption was applied to the meaning of 'registered operator' in Regulation 5 of the Transport Operations (Road Use Management-Vehicle Registration) Regulation 2010 (Qld), it would mean that the Regulation applied only to registered operators in Queensland, and that therefore only a person who was a registered operator in Queensland is entitled to a refund under Regulation 56, which is how the Regulations are currently applied by the Department of Transport.

The literal approach and the presumption against extraterritoriality thus lead to different conclusions as to the correct interpretation of the Regulations: Application of the literal approach leads to the result that out of State purchasers of vehicles are entitled to a refund. An application of the presumption against extraterritoriality leads to the result that they are not.

The next relevant principle of statutory interpretation is the presumption that legislation is presumed to be constitutional. Discussion of this rule requires that one first analyses s 92 of the Constitution and its impact on the Queensland Regulations, and so discussion of it is deferred to Part 5.

\section{Section 92 of the Commonwealth Constitution}

Section 92 of the Commonwealth of Australia Constitution Act 1901 (UK) provides as follows:

\section{Trade within the Commonwealth to be free}

On the imposition of uniform duties of customs, trade, commerce, and intercourse among the States, whether by means of internal carriage or ocean navigation, shall be absolutely free.

But notwithstanding anything in this Constitution, goods imported before the imposition of uniform duties of customs into any State, or into any Colony which, whilst the goods remain therein, becomes a State, shall, on thence passing into another State within two years after the imposition of such duties, be liable to any duty chargeable on the importation of such goods into the Commonwealth, less any duty paid in respect of the goods on their importation.

Only the first sentence of s 92 , in so far as it protects inter-State trade and commerce, is relevant to this article. ${ }^{16}$

The origin of s 92 lies in concerns on the part of the representatives of the Australian colonies participating in the Constitutional Conventions of the 1890s which had been convened to draft a constitution for an Australian federation, that trade and commerce between the States of the new federation should be free. ${ }^{17}$ Thus s 92 , along with other sections of the Constitution, such as s 51(ii) which prohibits the Commonwealth from discriminating between States in its imposition of taxation; s 90, which prohibits the States from imposing duties of customs and excise and s 99 which prohibits the Commonwealth from giving preference when it regulates trade, commerce or revenue to any State or part thereof as compared to another State or part thereof, was designed to serve the objective of economic integration within the federation.

Section 92 gave rise to interpretative difficulties. ${ }^{18}$ For most of the $20^{\text {th }}$ century, the courts interpreted s 92 as

\footnotetext{
${ }^{14}$ The presumption is discussed in Pearce, D. C. and Geddes, R. S., Statutory Interpretation in Australia (6 ${ }^{\text {th }}$ ed.). Chatswood: LexisNexis Butterworths, 168-71.

15 Jumbunna Coal Mine NLv Victorian Coal Miners' Assoc (1908) 6 CLR 309 at 363, O'Connor J.

${ }^{16}$ For a comprehensive analysis of s 92 and the case law that has arisen under it see Williams, G., Brennan, S. and Lynch, A. (2018). Australian Constitutional Law and Theory - Commentary and Materials. $\left(7^{\text {th }}\right.$ ed). Sydney: The Federation Press, 1274-94, and Meagher, D., Simpson, A., Stelios, J. and Wheeler, F. (2016). Hanks Australian Constitutional Law-Materials and Commentary (10 ${ }^{\text {th }}$ ed.). Chatswood: LexisNexis Butterworths.

17 The history of debate on this point at the Conventions and the purpose of s 92 are discussed in Quick J. and Garran R. (1901). The Annotated Constitution of the Australian Commonwealth. Sydney: Angus \& Robertson, 844-5.

${ }^{18}$ Harris, B. (2015). Constitutional Law Guidebook (2 ${ }^{\text {nd }}$ ed). South Melbourne: Oxford University Press, 212.
} 
embodying a laissez-faire theory, under which s 92 was interpreted as prohibiting any interference with interstate trade. The laissez-faire approach became redundant following the High Court's decision in Cole v Whitfield, ${ }^{19}$ in which the Court adopted an interpretation of s 92 based on the free trade doctrine, under which the section is interpreted as prohibiting only such interferences as discriminate against interstate trade in a protectionist manner, and as permitting regulation of interstate trade that is merely incidental to a non-discriminatory scheme.

Under this new approach, the High Court held that the word 'absolutely' in s 92 cannot be interpreted literally, noting that such a conclusion is consistent with the existence of the legislative power to regulate interstate trade contained in s 51(i) of the Constitution. The Court held that the purpose of s 92 was to prevent discrimination between interstate and intrastate trade, and that the essential test of whether a law infringes s 92 is whether it imposes a 'discriminatory burden of a protectionist kind.' The Court adopted a practical effect test in determining whether a suspect law was discriminatory, holding that a law will be found to discriminate against interstate trade either if it does so on its face, or if its practical effect is to single out interstate trade for differential treatment. It also held that, in determining whether a law is protectionist, the courts will inquire whether the law has the effect of protecting intrastate trade from the competition of interstate trade. The court also held that a law that is found to discriminate against interstate trade will nevertheless not fall foul of $\mathrm{s} 92$ if it has a non-protectionist purpose and if, in the light of the purpose, the protectionism it incidentally causes is not disproportionate in its extent.

The proportionality test was developed further in Castlemaine Tooheys Ltd $v$ South Australia. ${ }^{20}$ In that case, the High Court held that legislation that has the practical effect of discriminating against interstate trade in a protectionist manner will not fall foul of s 92 provided that it has a legitimate non-protectionist objective (broadly defined as protecting the community from danger or enhancing its welfare), that the legislation is either necessary to achieve the objective, that the protectionist effect of the legislation is only incidental to the achievement of the objective, and that there is proportionality between the objective achieved by the legislation and its protectionist effect.

In Betfair Pty Ltd $v$ Western Australia, ${ }^{21}$ the High Court applied the criteria established in Cole $v$ Whitfield and Castlemaine Tooheys Ltd v South Australia in holding that Western Australian legislation which prohibited the placing of bets via online betting exchanges breached s 92 . Betting exchanges operate by enabling customers to bet against each other, with the exchange operator charging a fee on each bet. The plaintiffs operated such an exchange in Tasmania, which took bets from gamblers all over Australia. The Court held that the effect of the legislation was to shield traditional bookmakers and fixed-odds totalisator operators within Western Australia from competition from betting exchange operators outside the State. In its judgment, the Court emphasised the need to determine the impact of such legislation on all market participants (both buyers and sellers), ${ }^{22}$ and to recognise that the growth of online commerce means that markets operate nationwide and so the effect of legislation which affects market participants must be analysed in light of that circumstance. ${ }^{23}$ The Court held that even though the Western Australian legislation prohibited the placing of bets on betting exchanges irrespective of whether they operated within the State or outside of it, the fact that Western Australia would not licence betting exchanges within the State meant that the practical effect of the legislation was to protect betting operators within the State from competition from operators in other States. Since Western Australia was unable to adduce evidence that the legislation served a legitimate non-protectionist objective, it was held to be invalid.

\section{The Queensland Legislation and s 92}

In determining whether the Queensland Regulations - as currently applied - breach s 92, it is necessary to apply the two-pronged test from Cole $v$ Whitfield, namely whether the challenged law imposes a 'discriminatory burden of a protectionist kind.' As noted in Part 3, the way in which the Regulations are currently applied has the consequence that a person living in another State or Territory who purchases a vehicle from Queensland will be unable to obtain a refund for the unexpired period of vehicle registration. This means that the Regulations discriminate between interstate and intrastate trade, and this amounts to what the court in Cole $v$ Whitfield referred to as a 'discriminatory burden' prohibited by s 92 .

The next question to determine is whether the discriminatory burden is 'of a protectionist kind.' Australia has a

\footnotetext{
19 (1988) 165 CLR 360.

${ }^{20}$ (1990) 169 CLR 436.

${ }^{21}$ (2008) 2324 CLR 418.

${ }^{22}$ Ibid 449.

${ }^{23}$ Ibid 452 and 480.
} 
nationwide market for motor vehicles. This is particularly true of second-hand vehicles, which are marketed on online internet sites. ${ }^{24}$ Many second-hand car dealers arrange for the transport of vehicles to buyers located in other parts of the country. Such services are particularly useful for buyers living in remote areas, where there may either be no dealerships or ones with only a restricted choice of vehicles. For these reasons, interstate purchases of motor vehicles are not uncommon. The price of a motor vehicle is affected by the number of months remaining on its registration. Thus the remaining registration forms an intangible part of the asset being purchased. Sellers and buyers engaging in contractual negotiations therefore take into account how many months of registration a vehicle has remaining on it. What is the effect on this market of the Queensland Regulations? Whereas purchasers of vehicles living in Queensland retain the value of the registration on the vehicle when they purchase it, the effect of the Regulations is that out of State purchasers forfeit that benefit. The consequence of this is that there is a disincentive on out of State purchasers to buy vehicles from Queensland. Whether intended or not, the economic effect of the Regulations is to shield purchasers of vehicles within Queensland from competition from out of State purchasers. The discriminatory burden the Regulations impose is therefore, in the words of the court in Cole $v$ Whitfield, 'of a protectionist kind.' On this basis one can say that the Regulations prima facie breach s 92 .

The final stage in the constitutional inquiry is to determine whether there is a legitimate non-protectionist objective served by the Regulations, which would lead to them escaping constitutional invalidity, in accordance with the doctrine regarding permissible regulation of interstate trade enunciated in Castlemaine Tooheys Ltd v South Australia. The authorising Act for the Regulations is the Transport Operations (Road Use Management) Act 1995 (Qld). Nothing in the Explanatory Notes ${ }^{25}$ published when the Act was introduced to Parliament referred to, or offered a rationale for, the differential treatment of interstate purchases of vehicles as compared to intrastate purchases in so far as refunds of licence fees are concerned. Nor was there any reference to the issue when the Bill was debated in Parliament. ${ }^{26}$ There is therefore no evidence which would support an argument that the protectionist measure is saved by a proportionate non-protectionist purpose and thus one must conclude that in so far as it denies a refund of licence fees to out of State purchasers, the Queensland Regulations are invalid for breach of $\mathrm{s} 92$.

This then brings one back to the interpretation of the Regulations. As noted in Part 3, a literal interpretation leads to the conclusion that a person outside Queensland who has purchased a Queensland-registered vehicle is entitled to a refund, whereas the presumption against extraterritoriality leads to the conclusion that they are not so entitled. In light of the analysis of the operation of s 92 in the preceding paragraphs of this Part, this leads to the conclusion that a literal interpretation leads to a constitutional result, whereas an application of the presumption against extraterritoriality leads to an unconstitutional result.

This then indicates the relevance of another presumption of statutory interpretation (discussion of which was noted, but deferred, in Part 3) which is that legislation is presumed to be constitutional. ${ }^{27}$ This presumption requires that, in cases of ambiguity, a court should interpret legislation in such a way as to operate constitutionally where the language allows. ${ }^{28}$ If, however, the language does not permit the legislation to be interpreted consistently with the constitution, the legislation will be found to be invalid to the extent that it is unconstitutional. This common law principle appears in legislative form in s 9(1) of the Acts Interpretation Act 1954 (Qld), which states that an Act is to be interpreted as not exceeding Parliament's legislative power. Given that denial of a refund breaches s 92, an application of this presumption to the term 'registered operator' in Regulation 5 would require a court to interpret the term as referring to any person who had registered the vehicle - whether in Queensland or elsewhere - so as to avoid the denial of a refund being found to be unconstitutional.

It is inevitable that judicial discretion plays a role in determining which of these rules to apply. ${ }^{29}$ Judicial discretion becomes particularly important where, as in this case, the rules clash: As noted above, an application of the common law literal approach, as well as the statutory presumption that a law is constitutional, leads to the conclusion that the correct interpretation of the Regulations is that they entitle interstate purchasers of Queensland registered vehicles to a refund of unexpired fees and that the denial of such refunds, which is

\footnotetext{
${ }^{24}$ See for example www.carsales.com.au and www.drive.com.au

${ }^{25}$ The notes can be accessed at https://www.legislation.qld.gov.au/view/pdf/bill.first.exp/bill-1995-235

${ }^{26}$ See Queensland Parliament Hansard, 23 February 1995, 11057- 11059 and 24 March 1995, 11372-11411.

${ }^{27}$ For a discussion of this presumption, see Pearce and Geddes, above n 14, 168.

${ }^{28}$ FCT v Munro; British Imperial Oil Co Ltd v FCT (1926) 38 CLR 153, 180 (Isaacs J) and Attorney-General (Vic) v Commonwealth (1945)

71 CLR 237, 267 (Dixon J).

${ }^{29}$ Ekins, R. and Goldsworthy, J., 'The Reality and Indispensability of Legislative Intentions' (2014) 36 Sydney Law Review 39, 62.
} 
currently the practice of the Queensland government, is therefore unlawful. By contrast, an application of the presumption against extraterritoriality - which is also statutory - leads to the conclusion the correct interpretation of the Regulations is that they do not entitle such purchasers a refund. This in turn would lead to the conclusion that the Regulations are unconstitutional and invalid in so far as they deny refunds to interstate purchasers.

A case involving the interpretation of the Regulations would therefore put a court in the difficult position of having to choose between two statutory rules of interpretation. Which of these conflicting courses a court would adopt is difficult to predict, but is ultimately irrelevant to the outcome, because whichever course was adopted, it would be found that the denial of refunds to interstate purchasers was unlawful and that the State government is liable to pay such refunds as it has withheld. The only limitation to that entitlement would be that arising from $\mathrm{s}$ 10(1)(d) of the Limitations Act 1974 (Qld), which imposes a six year limit between the time the cause of action arose and the bringing of the action.

\section{Suggested Course of Action}

Although the denial of refunds to interstate purchasers of Queensland motor vehicles is unlawful, litigants seeking to launch a legal challenge face the obvious practical difficulty that, because they live outside Queensland, it will be costly both in time and money for them to initiate proceedings in a Queensland court. Furthermore, as the amounts involved will be relatively small - the current annual licence fee for a four cylinder motor vehicle is $\$ 737.10,^{30}$ and so the refund on the unexpired portion of the registration will be some fraction of that - many potential litigants might take the view that a claim was not worth the cost and inconvenience involved in travelling to Queensland in order to bring an action. Given the enormous disparity in resources between private litigants and the government, the possibility of incurring costs would be far more of a concern to the former than the latter.

A possible solution to this would be for a number of litigants to initiate a class action. Class actions have become increasingly common in Australia, ${ }^{31}$ and a number of law firms specialise in them. There has also been a growth in the establishment of litigation funding companies, which pay the costs of litigation in exchange for a percentage of the damages awarded. ${ }^{32}$ The class of potential plaintiffs on whose behalf an action could be brought to recover un-refunded licence fees is potentially large, particularly given that the most populous area of Queensland is located in the south-east of the State, where the economy is closely integrated with that of northern New South Wales and where there is therefore likely to be a significant number of people who purchased vehicles from Queensland. The adoption of this strategy therefore provides the best avenue for recovery of the refunds unlawfully withheld.

\section{References}

Ekins, R., \& Goldsworthy, J. (2014). The Reality and Indispensability of Legislative Intentions. Sydney Law Review, 39.

Harris, B. (2015). Constitutional Law Guidebook (2nd ed.). South Melbourne: Oxford University Press.

Legg, M. (2017). Class Actions, Litigation Funding and Access to Justice. University of New South Wales Faculty of Law Research Series, 57.

Meagher, D., Simpson, A., Stelios, J., \& Wheeler, F. (2016). Hanks Australian Constitutional Law - Materials and Commentary (10th ed.). Chatswood: LexisNexis Butterworths.

Murphy, B., \& Cameron, C. (2006). Access to Justice and the Evolution of Class Action Litigation in Australia. Melbourne University Law Review, 30, 399.

Pearce, D. C., \& Geddes, R. S. (n.d.). Statutory Interpretation in Australia (6th ed.). Chatswood: LexisNexis Butterworths.

Queensland Government. (2018). Changing your registration-moving interstate or buying a Queensland registered vehicle. Retrieved from https://www.qld.gov.au/transport/registration/transfer/interstate

Queensland Government. (2019). Registration costs. Retrieved from https://www.qld.gov.au/transport/registration/fees/cost

\footnotetext{
${ }^{30}$ The fees for various types of vehicle are tabulated at https://www.qld.gov.au/transport/registration/fees/cost

${ }^{31}$ For an overview of class actions see Murphy, B. and Cameron, C. 'Access to Justice and the Evolution of Class Action Litigation in Australia,' (2006) 30 Melbourne University Law Review 399.

${ }^{32}$ Legg, M., 'Class Actions, Litigation Funding and Access to Justice' [2017] University of New South Wales Faculty of Law Research Series 57.
} 
Queensland Government. (2019). Transport Operations (Road Use Management) Bill - Explanatory Note. Retrieved from https://www.legislation.qld.gov.au/view/pdf/bill.first.exp/bill-1995-235

Queensland Legislative Assembly. (2019). Record of Proceedings (Hansard). Retrieved from https://www.parliament.qld.gov.au/work-of-assembly/sitting-dates/dates/1995

Quick, J., \& Garran, R. (1901). The Annotated Constitution of the Australian Commonwealth. Sydney: Angus \& Robertson

Williams, G., Brennan, S., \& Lynch, A. (2018). Australian Constitutional Law and Theory - Commentary and Materials (7th ed). Sydney: The Federation Press.

\section{Copyrights}

Copyright for this article is retained by the author(s), with first publication rights granted to the journal.

This is an open-access article distributed under the terms and conditions of the Creative Commons Attribution license (http://creativecommons.org/licenses/by/4.0/). 